\title{
Poster session
}

\author{
Hepatitis B surface antigen immunopurification \\ using a plant-derived specific antibody coupled to \\ Sepharose CL-4B at different ligand densities \\ Rodolfo Valdés, ${ }^{1}$ Yenisley Medina, ${ }_{1}^{1}$ William Ferro, ${ }^{1}$ \\ José A. Montero, ${ }^{1}$ Tatiana Alvarez, ${ }^{1}$ Déborah \\ Geada, ${ }^{2}$ Alberto Leyva, ${ }^{3}$ Leonardo Gómez, ${ }^{1}$ \\ Sigifredo Padilla, ${ }^{1}$ Biunayki Reyes, ${ }^{1}$ Leonardo \\ Pacín, ${ }^{1}$ Alejandro Figueroa, ${ }^{1}$ Andrés Tamayo, ${ }^{1}$ Lorely \\ Milá, ${ }^{4}$ Yurisleydi Aldama ${ }^{4}$ and María del Carmen \\ Abrahantes ${ }^{5}$ \\ ${ }^{I}$ Monoclonal Antibody Production Department, \\ ${ }^{3}$ Process Control Department, \\ ${ }^{4}$ Quality Control Direction, \\ ${ }^{5}$ Process Development Direction. Center for Genetic \\ Engineering and Biotechnology. P.O. Box 6162, \\ Havana 10600, Cuba \\ ${ }^{2}$ Tobacco Research Institute. Aguiar \#360 be/ Obispo \\ and Obrapía. Havana 10100, Cuba
}

Affinity separations are well stablished techniques for the purification and recovery of biological molecules. The high specificity inherent to immunoaffinity chromatography allows one step of purification to obtain highly pure and concentrated proteins from complex mixtures. Mouse monoclonal antibodies for the immunopurification of the Hepatitis B surface antigen (HBsAg) have been susccesfully used to obtain this antigen for human used as the active pharmaceutical ingridient of recombinant vaccines. This paper evaluates the immunopurification behavior of a plant-derived HBsAg specific antibody coupled to Sepharose CL4B at different ligand densities. It was purified from $400 \mathrm{~kg}$ of tobacco leave batches and coupled to the matrix at different ligand densities with high efficiency (>92\%). Results shown non significant differences in the adsorption and elution capacity, and rHBsAg recovery of $3.43,4.45$, and $5.31 \mathrm{mg} / \mathrm{mL}$ immunosorbents compared to its mouse-derived $\mathrm{mAb}$ counterpart coupled at the ligand density consistently used in the large-scale rHBsAg purification process $(3.82 \mathrm{mg} / \mathrm{mL})$. Therefore, ligand densities higher than $3.43 \mathrm{mg} / \mathrm{mL}$ do not improve the immunopurification behaviour, increase the antibody consumption and as consequence, the hepatitis B
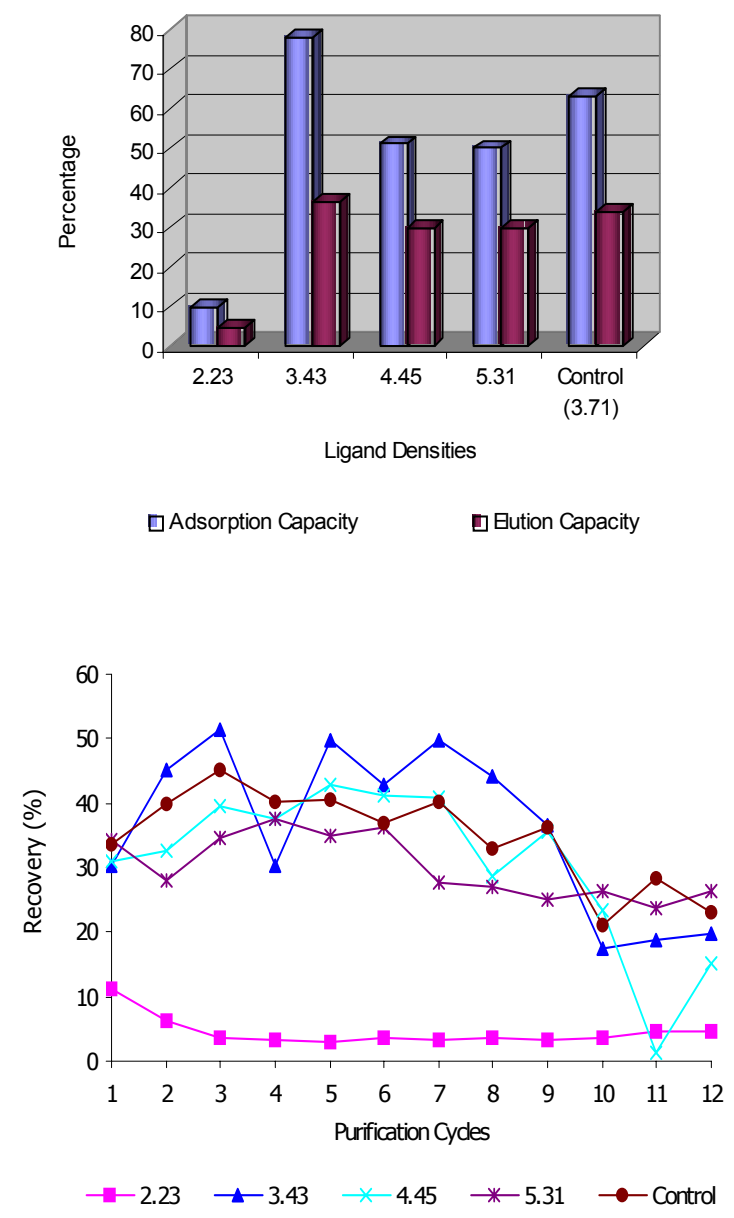

vaccine cost. Immunosorbent of $2.23 \mathrm{mg} / \mathrm{mL}$ of ligand desity demonstrated a poor performance. In addition, an IgG contamination $\leq 3 \mathrm{ngIgG} / \mu \mathrm{grHBsAg}$ has been previously established as the approved maximum IgG co-elution level, because the subsequent $\mathrm{HBsAg}$ purification process is able to assure a non immunogenic level of mouse IgG in the hepatitis $\mathrm{B}$ vaccine. The IgG detectable level never exceeded this limit. A value close to the limit was only observed at the ligand density of $5.31 \mathrm{mg} / \mathrm{mL}$, constituting this another aspect against the use of high ligand densities. In conclusion, it supports the 
feasibility of using this plantibody at $3.43 \mathrm{mg} / \mathrm{mL}$ of ligand density for large-scale immunopurification of this viral antigen for human use.

\section{Determination of the affinity constant and} specificity of a monoclonal antibody directed against the hepatitis $B$ surface antigen produced by transgenic plants, hollow fiber bioreactor and ascitic fluid

Leonardo Gómez, ${ }^{1}$ Rodolfo Valdes, ${ }^{1}$ Osvaldo Reyes, ${ }^{2}$ William Ferro, ${ }^{1}$ Déborah Geada ${ }^{3}$ and Sigifredo Padilla ${ }^{1}$

${ }^{1}$ Monoclonal Antibody Production Department, Center for Genetic Engineering and Biotechnology,. Ave 31 between 158 and 190, P. O. Box 6162, Havana 10600, Cuba

${ }^{2}$ Chemical and Physic Department, Center for Genetic Engineering and Biotechnology. Ave 31 between 158 and 190, P. O. Box 6162, Havana 10600, Cuba

${ }^{3}$ Tobacco Research Institute. Aguiar 360 bel Obispo and Obrapia. Old Havana, Havana, Cuba

The affinity constant and specificity of a monoclonal antibody directed against Hepatitis B surface antigen produced by transgenic plants was compared to its counterparts produced by hollow fiber bioreactors and ascitic fluid methods. The objective of this work was to investigate whether the monoclonal antibody production technology could induce change in the affinity constant and specificity of these molecules. The affinity constant was measured by an enzyme-linked immunosorbent assay based on the law of mass action and using serial dilutions of the antigen and antibody while the specificity was determined by mean of an assay in which the antibodies were faced to the Hepatitis B surface antigen peptides fixed in a cellulose membrane. Results indicate that the affinity constant of the monoclonal antibody CB.Hep-1 produced by these three different technologies is in the same order, $10^{8} \mathrm{Mol}^{-1}$ and the specificity assay demonstrated that these molecules recognized the aminoacid sequence CKTCTT of the Hepatitis B surface antigen. Therefore, the expression and production technologies do not induce changes in the affinity constant and neither in the specificity of this monoclonal antibody.

\begin{tabular}{lccc}
\hline Samples & $\begin{array}{c}\text { Affinity constant } \\
\left(\mathrm{M}^{-1}\right) \\
\text { Ascitic Fluid }\end{array}$ & $\begin{array}{c}\text { Affinity constant } \\
\left(\mathrm{M}^{-1}\right)\end{array}$ & $\begin{array}{c}\text { Affinity constant } \\
\left(\mathrm{M}^{-1}\right)\end{array}$ \\
1 & $3.4 \times 10^{8}$ & $1.6 \times 10^{7}$ & $\begin{array}{c}\text { Hollow Fiber } \\
\text { Bioreactor }\end{array}$ \\
\hline 2 & $2.3 \times 10^{8}$ & $6.6 \times 10^{10}$ & $1.6 \times 10^{7}$ \\
3 & $1.6 \times 10^{7}$ & $4.2 \times 10^{8}$ & $8.5 \times 10^{8}$ \\
4 & $4.6 \times 10^{8}$ & $3.3 \times 10^{10}$ & $4.3 \times 10^{8}$ \\
5 & $8.6 \times 10^{8}$ & $4.2 \times 10^{8}$ & $8.5 \times 10^{8}$ \\
7 & $1.1 \times 10^{8}$ & $2.1 \times 10^{8}$ & $2.6 \times 10^{9}$ \\
\hline
\end{tabular}
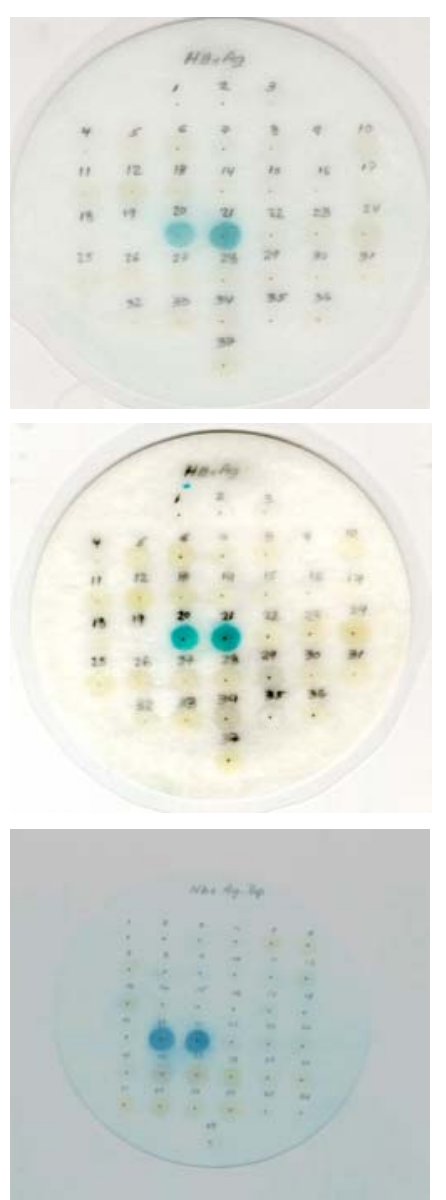

Fig. 1. Antigen recognition capacity of the monoclonal antibody CB.Hep-1 produced by three different technologies. A. ascitic fluid, B. hollow fiber bioreactor, $\mathrm{C}$ transgenic plants. 


\begin{abstract}
A rapid and sensitive ELISA to quantify a HBsAg specific monoclonal antibody and a plant-derived antibody during their downstream purification process

Alberto Leyva ${ }^{1}$, Julio C Sánchez ${ }^{1}$, Neyda

Hernández ${ }^{1}$, Abrisleida Franco ${ }^{1}$, Tatiana González ${ }^{1}$, Déborah Geada ${ }^{2}$, Ivette López ${ }^{1}$, Margela Montañés ${ }^{1}$, Iliana Delgado ${ }^{1}$ and Rodolfo Valdés ${ }^{1}$

${ }^{1}$ Center for Genetic Engineering and Biotechnology. P.O. Box 6162, Havana 10600, Cuba

${ }^{2}$ Cuban Institute of Tobacco Research. Km 81/2 Tumbadero Road. San Antonio de los Banos. Havana. Cuba
\end{abstract}

An enzyme-linked immunosorbent assay to quantify the mAb CB.Hep-1 during downstream purification process was standardized and validated. This assay is characterized by a short time of incubation at high temperature, allowing the detection of this antibody with high specificity and sensitivity. The immunoassay is linear in a range between 3.12 and 50 $\mathrm{ng} / \mathrm{mL}$, with a recovery of $98.55-107.62 \%$. According to results, it is possible to estimate the $\mathrm{mAb}$ CB.Hep-1 concentration with high precision and reproducibility. The intra- and interassay coefficient of variation ranged from 0.25 to $8.64 \%$ and 1.84 to $9.43 \%$ respectively. Significant differences were not observed in the plant-derived antibody quantification by HRP-ELISA and PhoA-ELISA ( $\mathrm{n}=18)$, demonstrating that plant endogenous peroxidases do not produce interferences in the quantification of this molecule. Therefore, both antibodies can be tested with the same immunoassay with high precision, specificity and accuracy during their respective purification processes without interference of the buffers and sample characteristics.

Table 1

Intra-and inter assay coefficients of variation $(\mathrm{CV})$ four experimental conditions

\begin{tabular}{|c|c|c|c|c|}
\hline \multirow[t]{3}{*}{ Sample } & \multicolumn{4}{|c|}{ Plant-derived antibody concentration $(\mu \mathrm{g} / \mathrm{mL})$} \\
\hline & \multicolumn{2}{|c|}{ Intra-assay } & \multicolumn{2}{|c|}{ Inter-assay } \\
\hline & Mean & $\% \mathrm{CV}$ & Mean & $\% \mathrm{CV}$ \\
\hline I & 29.1 & 4.28 & 28.1 & 1.46 \\
\hline II & 27.3 & 0.28 & 30.3 & 6.33 \\
\hline III & 21.3 & 4.01 & 21.5 & 15.3 \\
\hline IV & 34.8 & 3.58 & 35.5 & 16.21 \\
\hline $\mathrm{V}$ & 157.8 & 3.07 & 159.1 & 7.22 \\
\hline
\end{tabular}

I, II, III, IV, and V are the production process's sample at different purification stages. SD, standard deviation; CV (\%), coefficient of variation.

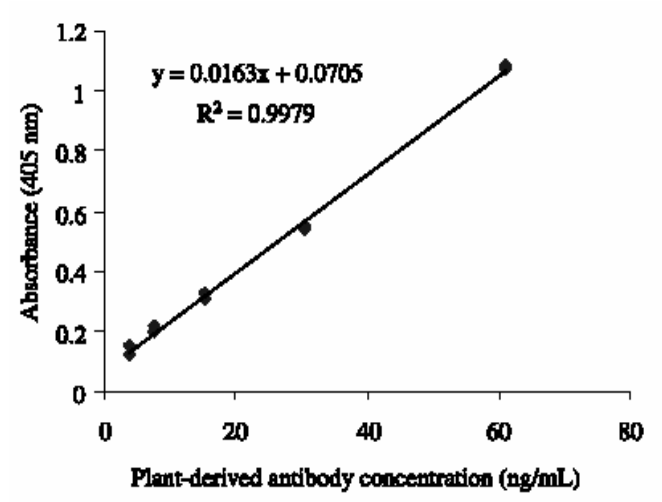

Fig. 1. Standard curve for quantification of the plant-derived antibody HB-01 expressed in Nicotiana tabacum plants.

Conclusions: A rapid ELISA capable of measuring the mAb CB.Hep-1 and its plant-derived antibody HB-01 counterpart with specificity, reproducibility and a high accuracy was developed and validated. This immunoassay may be useful for monitoring both antibodies throughout the downstream purification process without interference.

- The linear range of the standard curve was from 3.12 to $50 \mathrm{ng} / \mathrm{mL}$.

- Interassay and intra-assay precision ranged from $1.84 \%$ to $9.43 \%$ and from $0.25 \%$ to $8.64 \%$, respectively.

- $\quad$ The recovery range was from 98.55 to $107.62 \%$.

- Endogenous peroxidases produced by the transgenic plants not interfere in the quantification of the plant-derived antibody HB-01.

\section{LATE POSTERS}

Gangliosides, AB1 and AB2 antibodies.

I. Towards a molecular dissection of an idiotypeanti-idiotype system

Alejandro López-Requena ${ }^{\mathrm{a}}$, Cristina Mateo de Acosta $^{a}$, Ernesto Moreno ${ }^{a}$, Majela González ${ }^{a}$, Yaquelin Puchades ${ }^{\mathrm{b}}$, Ariel Talavera ${ }^{\mathrm{a}}$, Nelson SantiagoVispo $^{\mathrm{b}}$, Ana María Vaázquez ${ }^{\mathrm{a}}$ and Rolando Pérez ${ }^{\mathrm{a}}$

${ }^{a}$ Centre of Molecular Immunology, Havana, Cuba

${ }^{b}$ Centre of Genetic Engineering and Biotechnology, Havana, Cuba

Tel.: 5372714335 ; E-mail: cristina@ict.cim.sld.cu

This study is focused on the molecular basis for the interaction of a monoclonal antibody $(\mathrm{mAb})$ and its anti-idiotypic mAb. P3 mAb (Ab1) recognizes $N$ - 
glycolyl-gangliosides, and $1 \mathrm{E} 10 \mathrm{mAb}$ is one of its anti-idiotypic mAbs (Ab2). Chimeric versions of both antibodies retained their specificity. Charged residues in their $\mathrm{H}-\mathrm{CDRs}$, particularly $\mathrm{H}-\mathrm{CDR} 3$, were considered to play a major role in their binding and immunogenic properties. $\mathrm{P} 3 \mathrm{mAb}$ has the unusual property of generating a strong antibody response in syngeneic mice, even when it is administered in saline. We selected phagotopes from a $12 \mathrm{mer}$ peptide library displayed on filamentous phage to characterize amino acid motifs recognized by these antibodies. The peptides were enriched in charged amino acids similar to those present in P3 and 1E10 $\mathrm{mAb} \mathrm{H}-\mathrm{CDR} 3$. We also report the construction of four mutants of the $\mathrm{P} 3$ antibody, where arginine residues in the heavy chain CDRs were substituted by serine residues, and the characterization of their interaction with $1 \mathrm{E} 10 \mathrm{mAb}$ and $\mathrm{GM} 3(\mathrm{NeuGc})$ ganglioside, as well as their immunogenic properties in $\mathrm{Balb} / \mathrm{c}$ mice. $\mathrm{H}-\mathrm{CDR} 1 \mathrm{R}_{31}$ residue appears to have a central role in $\mathrm{P} 3 \mathrm{mAb}$ reactivity and antigenicity. $\mathrm{H}-$ CDR3 $R_{100 a}$ residue seems to be more involved in the immunogenicity of the $\mathrm{P} 3$ idiotype.

\section{Rapid reformatting of antibodies from phage to IgGs}

Stan Lee, Dan Sexton, Niksa Kastrapeli, Aaron Sato, Csaba Pazmany, Judy Jacques and Kristin Rookey

Tissue kallikrein 1 (hK1 or KLK1 gene product) is a member of the tissue kallikrein family of serine proteases and a component of the kallikrein-kinin system. This biological system is responsible for the production of kinins, which are potent mediators of inflammation. Kinins are elevated in the bronchoalveolar lavage of asthma patients and nasal lavage of patients with allergic rhinitis. The inhalation of bradykinin leads to bronchoconstriction in asthmatic subjects. We identified several high affinity human antibodies $(\mathrm{KD}<1 \mathrm{nM})$ that bind and inhibit the protease activity of hK1 using phage display. These antibodies are highly selective inhibitors of hK1 and inhibit the kininogenase activity of hK1. DX-2300 is one of the most potent antibody inhibitors of hK1 that we discovered $(\mathrm{Ki}=60 \mathrm{pM})$ and was found to be efficacious in an allergic sheep model of asthma. Sheep treated with $10 \mathrm{mg}$ DX-2300 (inhaled) prior to challenge with Ascaris suum inhibited late phase bronchoconstriction by over $80 \%$ and completely blocked airway hyperresponiveness to carbachol. These studies indicate a role for hK1 in airway diseases and suggest that specific hK1 antibody inhibi- tors may represent a novel class of therapeutic agents for the treatment of respiratory diseases.

Herein, we describe the discovery of DX-2300, the reformatting, and the expression of the antibody from phage to fully human IgG through the Dyax compatible vectors. The antibody libraries are especially powerful due to the ease of use whereby one can efficiently transfer selected Fabs from display vectors to bacterial soluble Fab or mammalian $\mathrm{IgG}$ vectors. Transfer is performed by "cut and paste" restriction fragment cloning. The linkage of light and heavy chain is maintained, thus allowing populations to be cloned without repertoire shuffling. This poster will focus on the technology and methods used to reformat DX-2300 from Fab displaying phage to soluble Fab followed by fully human IgG and supporting expression data.

In vitro anti-tumoral activity of baculovirusexpressed chimeric recombinant anti-CD4 antibody 13B8.2 on $T$ cell lymphomas

Samuel Troadec ${ }^{1}$, Myriam Chentouf ${ }^{1}$, Martine Cérutti $^{1}$, Gaspard Cretennet ${ }^{1}$, Brigitte Nguyen ${ }^{1}$, Daniel Olive ${ }^{2}$, Cédric Bès ${ }^{1}$ and Thierry Chardès ${ }^{1}$

${ }^{I}$ CNRS UMR 5160, Centre de Pharmacologie et Biotechnologie pour la Santé, Faculté de Pharmacie, 15 avenue Charles Flahault, BP 14491, 34093 Montpellier Cedex 5, France

${ }^{2}$ Laboratoire d'Immunologie des tumeurs, Institut Paoli-Calmettes, 232 boulevard Sainte-Marguerite, 13273 Marseille Cedex 09, France

We developed a new baculovirus-expressed chimeric recombinant $\operatorname{IgG}_{1}\left(\mathrm{rgG}_{1}\right)$ antibody derived from the monoclonal antibody $13 \mathrm{~B} 8.2$, which is specific for the CDR3-like loop of the CD4 molecule; this region being not exploited as a target by clinical antibodies. The aim of our study was to investigate the potential anti-tumor activity of this recombinant antibody onto $\mathrm{CD}^{+} \mathrm{T}$ lymphoma cell lines, prior to testing in pre-clinical trials of murine xenograft. By using ELISA, flow cytometry and cytotoxicity assays we tested the ability of $\operatorname{rgG}_{1} 13 \mathrm{~B} 8.2$ to inhibit the cell growth of $\mathrm{CD}^{+} \mathrm{T}$ cell lymphomas, to interact with the $\mathrm{Clq}$ fraction and mediate complementdependent cytotoxicity, and to bind to $\mathrm{F} c \gamma$ receptors and trigger antibody-dependent cellular cytotoxicity. Treatment of $\mathrm{CD}^{+} \mathrm{T}$ cell lymphomas with baculovirus-expressed $\mathrm{rIgG}_{1} 13 \mathrm{~B} 8.2$ led to the proliferation inhibition of lymphoblastic and acute $\mathrm{CD}^{+} \mathrm{T}$ cell lines, but did not affect cell cycle nor induced apoptosis. $\mathrm{rgG}_{1} 13 \mathrm{~B} 8.2$ bound $\mathrm{C} 1 \mathrm{q}$ from complement 
classical pathway and subsequently induced complement-dependent cytotoxicity of acute and cutaneous $\mathrm{CD}^{+} \mathrm{T}$ cell lines, which is correlated with CD59 cell level. Antibody-dependent cellular cytotoxicity on acute and cutaneous $\mathrm{CD} 4^{+} \mathrm{T}$ cell lines was mediated by $\mathrm{rgG}_{1} 13 \mathrm{~B} 8.2$ through its ability to bind $\mathrm{Fc} \gamma$ receptors. CD4 site numbers on $\mathrm{T}$ cell lymphomas correlated with cell sensitivity to $\mathrm{rgG}_{1} 13 \mathrm{~B} 8.2$ induced growth inhibition and -complement dependent cytotoxicity. These data offer a first in vitro rationale supporting the therapeutic use of baculovirusexpressed chimeric $\mathrm{rIgG}_{1} 13 \mathrm{~B} 8.2$ directed to the CD4-CDR3-like loop in $\mathrm{CD}^{+}$malignant diseases.

\section{Generation of anti-Neu-glycolyl-ganglioside anti- bodies by immunization with an anti-idiotype monoclonal antibody: A self versus non-self matter \\ Ana María Hernández ${ }^{1}$, Mabel Rodríguez ${ }^{1}$, Alejandro López-Requena, Irene Beausoleil, Rolando Pérez and Ana María Vázquez* \\ Department of Antibody Engineering, Center of Molecular Immunology, P.O. Box 16040, Havana 11600, Cuba \\ ${ }^{1}$ Both authors equally contributed to this work Tel.: 537 2716810; Fax: 537 2720644; E-Mail: maruchi@ict.cim.sld.cu}

We have previously generated a murine antiidiotype (Ab2) monoclonal antibody (mAb) to a murine $\mathrm{Ab} 1 \mathrm{mAb}$, named $\mathrm{P} 3$, which selectively binds NeuGc-sialic acid on several monosialo- and disialogangliosides, and also reacts with sulfatides and antigens expressed in human melanoma and breast tumors. This Ab2 mAb, designated as 1E10, induced anti-anti-idiotype antibodies (Ab3) in mice and cancer patients. These Ab3 generated by $1 \mathrm{E} 10 \mathrm{mAb}$ were characterized by bearing P3 mAb idiotopes $(\mathrm{Ab} 3, \mathrm{Id}+)$. But when the specificity of these Ab3 antibodies was tested, no specific humoral response against NeuGc-containing gangliosides was detected in sera from immunized mice. However, hyperimmune sera from melanoma and breast cancer patients vaccinated with this $\mathrm{Ab} 2 \mathrm{mAb}$ were able to react specifically with these gangliosides. The different expression of NeuGc-containing gangliosides in the normal tissues of mice and humans could explain these results. In order to demonstrate these findings in other animal species with a different NeuGc-sialic acid expression, we performed similar studies in monkeys and chickens. In monkeys, as in most mammals, NeuGc-containing gangliosides are self antigens. In contrast, chickens, like humans, lack the expression of these antigens in normal tissues. Here we report that the antibody response against NeuGccontaining gangliosides induced by immunization with $1 \mathrm{E} 10 \mathrm{mAb}$ was completely different in both species. No specific antibody response against these gangliosides was detected in hyperimmune monkey sera. In contrast, a strong and specific Ab3 response against $\mathrm{GM}_{3}(\mathrm{NeuGc})$ and $\mathrm{GM}_{2}(\mathrm{NeuGc})$ gangliosides $(\mathrm{Ab} 3, \mathrm{Ag}+)$ was generated in chickens due to the administration of $1 \mathrm{E} 10 \mathrm{mAb}$.

A rapid and sensitive ELISA to quantify a HBsAg specific monoclonal antibody and a plant-derived antibody during their downstream purification process

A. Leyva, A. Franco a, T. González a J. C. Sánchez ${ }^{a}$, I. López $z^{\mathrm{a}}, \mathrm{D}$. Geada ${ }^{\mathrm{b}}$, N. Hernández $z^{\mathrm{a}}$, M. Montañés ${ }^{\mathrm{a}}$, I. Delgado a and R. Valdés ${ }^{\mathrm{c}}$

a Process Control Department, Center for Genetic Engineering and Biotechnology, P.O. Box 6162, Havana 10600, Cuba

${ }^{\mathrm{b}}$ Tobacco Research Institute, Aguiar \#360 bel Obispo and Obrapía, Havana 10100, Cuba

${ }^{\mathrm{c}}$ Monoclonal Antibody Production Department, Center for Genetic Engineering and Biotechnology, P.O. Box 6162, Havana 10600, Cuba

Introduction: Monoclonal antibody technology has opened many doors in the biotechnology area, allowing the diagnosis of many diseases and treatment of illnesses such as infections, cancer among others. CB.Hep-1 is a mouse monoclonal antibody used as immunoligand in the downstream purification process of HBsAg, which is employed for a commercially available recombinant vaccine against the Hepatitis B virus (HeberBiovac HBTM, Heber Biotec SA, Cuba) [1]. Several alternatives of production of this $\mathrm{mAb}$ have been carried out [2]. Within these technologies, transgenic plants offer numerous advantages for the production of $\mathrm{mAb}$; namely cost efficiency, ease of handling, and ease of scale-up and biological safety [3].

One of the most commonly used bioanalytical methods to measure the protein concentration is the ELISA, due to its high specificity and sensitivity, allowing the accurate detection of a given protein during its purification process. However, these assays often require long time for the target protein determination and a detailed validation study before its application.

This work describes the standardization and validation of a rapid and quantitative ELISA for monitoring the mAb CB.Hep-1 during its downstream 
purification process, which requires minimal manipulation, and allows the precise detection and simple analysis of the samples. Furthermore, results obtained from the application of this HRP-ELISA were compared with an alkaline phosphatase ELISA specific to the plant-derived antibody HB-01, mAb CB.Hep-1 counterpart produced at large-scale from Tobacco plants [4], to detect possible interferences of the endogenous peroxidases produced by the transgenic plants.

Materials and methods: ELISA procedure:Microtiter plates (Nunc Maxisorp ${ }^{\circledR}$, Life Technologies, Roskilde, Denmark) were coated with 5 $\mu \mathrm{g} / \mathrm{mL}$ of recombinant HBsAg in carbonate/bicarbonate buffer, $\mathrm{pH}$ 9.6. After incubated for 20 min at $50{ }^{\circ} \mathrm{C}$, plates were washed with washing buffer (PBS containing 0.05\% Tween 20). Samples, standard, and control were diluted in PBS, $0.2 \%$ of BSA, $0.005 \%$ Tween 20 and incubated again during $20 \mathrm{~min}$ at $50{ }^{\circ} \mathrm{C}$. Subsequently; wells were washed five times and incubated with $100 \mu \mathrm{L} /$ well of a goat anti-mouse IgG horseradish peroxidase conjugate in a 1:30 000 dilution for $20 \mathrm{~min}$ at $50{ }^{\circ} \mathrm{C}$. Plates were finally washed and the reaction was revealed using ophenylenediamine (OPD) as substrate and $0.015 \%$ $\mathrm{H} 2 \mathrm{O} 2$ in citrate buffer ( $\mathrm{pH} \mathrm{5.0)}$. After $15 \mathrm{~min}$, the reaction was stopped by adding $50 \mu \mathrm{L}$ of $2 \mathrm{M}$ $\mathrm{H} 2 \mathrm{SO} 4$, and immediately read at $492 \mathrm{~nm}$ using a microELISA reader (Labsystem, Helsinki, Finland).

Statistical analysis: Linearity was determined using the least-squares method and the criteria for acceptance linearity were $\pm 20 \%$ recovery. The regression coefficient (r2), y-intercept, slope of the regression line, and residual sum of squares were also analyzed. Working range was established between

Table 1

Standard curve of monoclonal antibody CB.Hep-1

\begin{tabular}{llllll}
\hline \multirow{5}{*}{ assays } & \multicolumn{5}{l}{ Standard curve $(\mathrm{ng} / \mathrm{mL})$} \\
\cline { 2 - 6 } 1 & 50 & 25 & 12,5 & 6,25 & 3,12 \\
\hline 2 & 50.14 & 24.85 & 12.12 & 6.34 & 3.23 \\
3 & 49.53 & 25.15 & 11.99 & 6.36 & 3.36 \\
4 & 50.36 & 24.94 & 13.34 & 6.4 & 3,14 \\
5 & 48.33 & 27.91 & 14.31 & 5.62 & 3.24 \\
& 49.44 & 26.28 & 13.5 & 6.17 & 3.02 \\
mean & 49.56 & 25.83 & 13.05 & 6.18 & 3.21 \\
SD & 0.79 & 1.3 & 0.98 & 0.32 & 0.14 \\
\% CV & 1.6 & 5.03 & 7.53 & 5.25 & 4.39 \\
\% recovery & 99.49 & 101.32 & 103.9 & 100.58 & 91.13 \\
\hline
\end{tabular}

the highest and lowest concentration values with satisfactory accuracy and precision. The intra-assay variability was determined by a repeated measurement of the sample values in the same plate. The interassay variability was tested by three analysts for each assay at different times. For both precision assays described above, the acceptance criteria were less than 10 and $20 \%$ respectively. Nine determinations over three concentration levels of the standard spiked with three different concentrations of the sample were achieved. In this case, the recovery was tested for $6.25,12.5$, and $25 \mathrm{ng} / \mathrm{mL}$ values of concentration in the standard curve and confirmed with the Student's-test.

Results: Linearity and working range: In this case, we found the best linear curve fit for the concentration range from 3.12 to $50 \mathrm{ng} / \mathrm{mL}$. Recovery of all points of the standard curve ranged from 90 to 110 $\%$, and the CV \% values were, $<20 \%$ (Table 1 ).

Specificity and sensitivity: The specificity of the assay was assessed comparing the slopes of the standard curves in the working buffer with other curves in ascitic fluid obtained from mice inoculated with parenteral myeloma cells (ascites free of $\operatorname{IgG}$ ) spiked with the standard IgG and crude extract of tobacco plant (Fig. 1). Student's-test used in this study, reveled a good parallelism among curves, indicating the lack of interference in the working range.

Precision and accuracy of the assay: Interassay (intermediate) and intra-assay (repeatability) precision ranged from $1.84 \%$ to $9.43 \%$ and from $0.25 \%$ to $8.64 \%$, respectively (Table 2 ). The recovery range was from 98.55 to $107.62 \%$ which confirmed the reliability of this assay (Table 3 ).

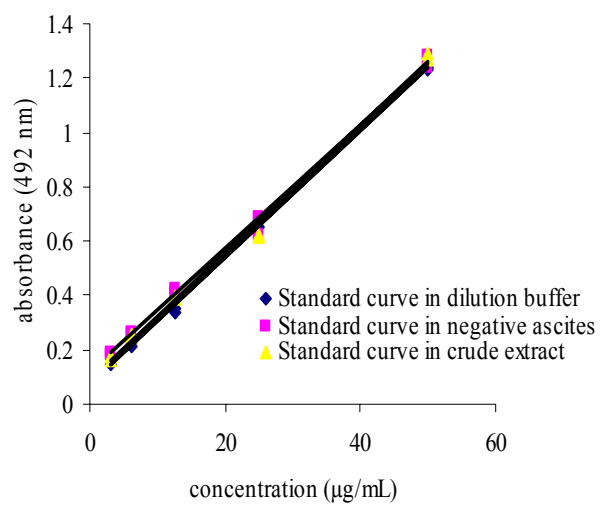

Fig. 1. Comparison between the standard curve in working buffer, negative ascites and crude extract of tobacco plant. 
Table 2

Precesion for intra- and interassay CVs in three different assays

\begin{tabular}{|c|c|c|c|c|c|c|c|}
\hline \multirow[t]{3}{*}{ Replicates } & \multicolumn{6}{|l|}{$\% \mathrm{CV}$} & \multirow{3}{*}{ inter-analyst } \\
\hline & \multicolumn{2}{|l|}{ analyst 1} & \multicolumn{2}{|l|}{ analyst 2} & \multicolumn{2}{|l|}{ analyst 3} & \\
\hline & intra-assay & interassay & intra-assay & interassay & intra-assay & interassay & \\
\hline 1 & 1.1 & 5.14 & 3.56 & 8.09 & 0.44 & 8.79 & 12.01 \\
\hline 2 & 0.49 & 3.28 & 1.83 & 8.66 & 8.29 & 1.84 & \\
\hline 3 & 5.75 & 5.66 & 5.13 & 7.86 & 5.07 & 9.43 & \\
\hline 4 & 7.09 & 5.16 & 6.37 & 6.67 & 0.25 & 3.66 & \\
\hline 5 & 4.14 & 6.98 & 1.94 & 3.87 & 1.7 & 8.8 & \\
\hline 6 & 6.74 & 7.44 & 4.03 & 5.69 & 8.64 & 4.09 & \\
\hline
\end{tabular}

Peroxidase activity: A specific stain was used to determine peroxidases in every production process samples (Fig. 2). In the crude, extract and filtered juice, the enzymatic activity was observed; however, it was totally eliminated in the purified antibody demonstrating that the final sample is free of peroxidases, and the efficiency of the protein A affinity chromatography in the purification of IgG molecules.

Comparison between PhoA-ELISA and HRPELISA: Downstream purification process samples of the plant-derived antibody HB-01 were tested by both HRP-ELISA and PhoA-ELISA. This includes mainly samples that containing vegetable extract. As shown in Table 4, we carry out a statistical comparison of each analyzed sample, using the t-test for 18 determinations per sample assuming equal variances.

Discussion: The correct quantification of a given protein is essential to its subsequent characterization and application. With this purpose, a simple and rapid HRP-ELISA was developed and validated to evaluate the production of the mAb CB.Hep-1, routinely used as ligand in the immunopurification of the HBsAg for human vaccine. This assay is based on its high temperature, which permits a short time of incubation without affecting the binding antigenantibody in the range of concentration from 3.12 to $50 \mathrm{ng} / \mathrm{mL}$, which demonstrates the higher sensitivity of this assay in respect to other reported ELISA [5]. The lower values of CV for intra-assay (0.25-8.64\%) and the interassay (1.84-9.43\%) obtained in the assay, were comparable with values reported by other researchers [5]. The mAb CB.Hep-1 was expressed in tobacco plant by means of the biological transformation method with the Agrobacterium tumefaciens containing a plasmid bearing the genes encoding the heavy and light chains of this antibody [6] and subsequently produced at large-scale [4]. During the downstream purification process of this plantibody many contaminant proteins, as peroxidase enzymes, are present in the process samples. Horseradish peroxidase and alkaline phosphatase are the two mostly widely used labels in the development of enzyme immunoassay. However, phosphatase labeled conjugated are often employed where HRP conjugates should not be used because of the presence of high endogenous peroxidase activity. In this study, the effects of endogenous peroxidase produced by transgenic plants have been exhaustively evaluated for the measurement of the plant-derived antibody HB-01. As part of our work strategy, the HRP-ELISA was compared with a recently validated immunoassay using alkaline phosphatase to quantify this antibody expressed in Nicotiana tabacum [6]. The $\mathrm{P}(\mathrm{Ttab}<\mathrm{Texp})$ used in the statistical analysis were $0.752,0.177,0.001$ respectively, proving that the peroxidases present in the samples do not interfere in the correct quantification of plant-derived antibody HB-01 when HRP labeled conjugate is used. This demonstrated no significant differences in the quantification of the plantibody HB-10 when tested by both ELISAs.

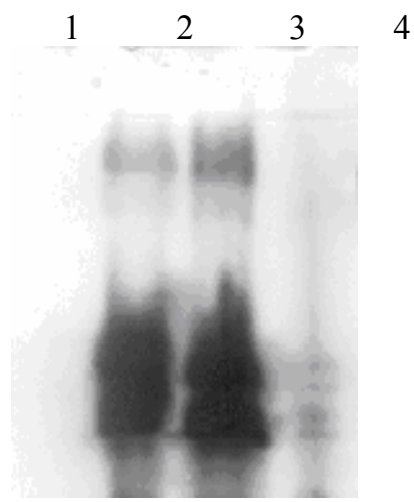

Fig. 2. Peroxidase presence in production. Samples of plantderived antibody HB-01. Revealed in polacrilamide gels. Lane 1, purified plantibody HB-01; lane 2, crude extract; lane 3, clarified extract; lane 4, filtrered juice. 
Table 3

Statistical analysis of the accuracy

\begin{tabular}{|c|c|c|c|c|c|c|}
\hline \multirow[b]{2}{*}{ assays } & \multicolumn{6}{|c|}{$\%$ Recovery } \\
\hline & \multicolumn{2}{|c|}{$25 \mathrm{ng} / \mathrm{mL}$} & \multicolumn{2}{|c|}{$12.5 \mathrm{ng} / \mathrm{mL}$} & \multicolumn{2}{|c|}{$6.25 \mathrm{ng} / \mathrm{mL}$} \\
\hline 1 & \multicolumn{2}{|c|}{102.36} & \multicolumn{2}{|l|}{95.36} & \multicolumn{2}{|l|}{99.57} \\
\hline 2 & \multicolumn{2}{|c|}{98.89} & \multicolumn{2}{|l|}{110.31} & \multicolumn{2}{|l|}{89.65} \\
\hline 3 & \multicolumn{2}{|c|}{105.25} & \multicolumn{2}{|l|}{115.62} & \multicolumn{2}{|l|}{106.44} \\
\hline media & \multicolumn{2}{|c|}{102.17} & \multicolumn{2}{|l|}{107.1} & \multicolumn{2}{|l|}{98.55} \\
\hline SD & \multicolumn{2}{|c|}{3.18} & \multicolumn{2}{|l|}{10.51} & \multicolumn{2}{|l|}{8.44} \\
\hline $\mathrm{CV}$ & \multicolumn{2}{|c|}{3.12} & \multicolumn{2}{|l|}{9.81} & \multicolumn{2}{|l|}{8.56} \\
\hline $\mathrm{T} \exp$ & \multicolumn{2}{|c|}{-0.41} & 1.28 & & \multicolumn{2}{|l|}{-1.44} \\
\hline $\mathrm{T}$ tab & \multicolumn{2}{|c|}{2.31} & & & & \\
\hline \multicolumn{7}{|c|}{$\begin{array}{c}\text { Table } 4 \\
\text { Statistical comparison between ELISA I and ELISA II in three } \\
\text { samples of the downstream purification process of the } \\
\text { plant-derived antibody }\end{array}$} \\
\hline \multirow[b]{2}{*}{ statistic } & I & II & I & II & I & II \\
\hline & \multicolumn{2}{|c|}{ crude extract } & \multicolumn{2}{|c|}{ clarified extract } & \multicolumn{2}{|c|}{$\begin{array}{l}\text { purified } \\
\text { plantibody }\end{array}$} \\
\hline mean & 1.59 & 1.6 & 1.49 & 1.47 & 2.78 & 2.81 \\
\hline SD & 0.04 & 0.02 & 0.03 & 0.03 & 0.03 & 0.02 \\
\hline $\mathrm{CV}$ & 2.3 & 1.51 & 2.29 & 2.34 & 1.12 & 0.83 \\
\hline $\mathrm{T} \exp$ & 0.752 & & 0.177 & & 0.001 & \\
\hline
\end{tabular}

$\mathrm{T}$ tab $=2.11$

I: PhoA-ELISA.

II: HRP-ELISA.

Conclusion: A rapid ELISA capable of measuring the $\mathrm{mAb}$ CB.Hep-1 and its plant-derived antibody HB-01 counterpart with specificity, reproducibility and a high accuracy was developed and validated. This immunoassay may be useful for monitoring both antibodies throughout the downstream purification process without interference of the endogenous peroxidase produced by tobacco plants.

\section{References}

[1] Pentón E, Herrera L, Muzio V, Ramírez V, García A, Duarte C, Ruiz C, Izquierdo M, Pérez L, Fontirrochi G, González M, Nazabal M, Beldarrain A, Padrón G, García J, de la Riva G, Santiago A, Ayan F, Páez R, Agraz A, Díaz R, Quiñónez Y. Method for obtaining recombinant surface antigen of hepatitis B virus of higher immunogenic capacity and use there of in vaccine preparation. Eur. Pat. Apl 1992; 480: p 525.

[2] Fontirrochi G, Dueñas M, Fernandez de Cossio ME, Fuentes P, Pérez M, Mainet D, Ayala M, Gavilondo JV, Duarte C. A mouse hybridoma cell line secreting IgG and IgM antibodies with specificity for the Hepatitis B virus surface antigen. Biotecnol. Aplicada 1993; 10: p. 24-30.

[3] Valdés R, Reyes B, Alvarez T, García J, Montero JA, Figueroa A, Gómez L, Padilla S, Geada D, Abrahantes MC, Dorta
L, Fernández D, Mendoza O, Ramirez N, Rodríguez M, Pujol M, Borroto C, Brito J. Hepatitis B surface antigen immunopurification using a plant-derived antibody produced in large scale. Biochem. Biophys. Res. Commun, 2003; 310: p. 742-747.

[4] Valdés R, Gómez L, Padilla S, Brito J, Reyes B, Alvarez T, Mendoza O, Herrera O, Ferro W, Pujol M, Leal V, Linares M, Hevia Y, García C, Milá L, García O, Sánchez R, Acosta A, Geada D, Paez R, Vega JL, Borroto C. Large-scale purification of an antibody directed against hepatitis B surface antigen from transgenic tobacco plants. Biochem Biophys. Res Commun 2003; 308: p. 94-100.

[5] Jilani I, Keating M, Gile JF, O'Brien S, Kantarjian HM, Albitar M. Alentuzumab: validation of a sensitive and simple enzyme-linked immunosorbent assay. Leukemia Research 2004; 28: p.1255-1262

[6] Ramírez N, Rodríguez M, Ayala M, Cremata J, Pérez M, Matínez A, Linares M, Hevia Y, Páez R, Valdés R, Gavilondo JV, Selman-Housein G. Expression and characterization of an anti-(hepatitis B surface antigen) glycosylated mouse antibody in transgenic tobacco (Nicotiana tabacum) plants and its use in the immunopurification of its target antigen. Biotechnol. Appl. Biochem 2003; 38: p. 223-230.

Hepatitis B surface antigen immunopurification using a plant-derived specific antibody coupled to Sepharose CL-4B at different ligand densities R. Valdés, ${ }^{1}$ Y. Medina, ${ }^{1}$ W. Ferro, ${ }^{1}$ J. Montero, ${ }^{1}$ T. Alvarez, ${ }_{1}^{1}$ D. Geada, ${ }^{2}$ A. Leyva, ${ }^{3}$ L.Gómez, ${ }^{1}$ S. Padilla, ${ }^{1}$ B. Reyes, ${ }^{1}$ L. Pacín, ${ }^{1}$ A. Figueroa, ${ }^{1}$ A. Tamayo, ${ }^{1}$ Y. Aldama, ${ }^{4}$ and MC. Abrahantes ${ }^{5}$ ${ }^{I}$ Monoclonal Antibody Production Department,

${ }^{3}$ Process Control Department,

${ }^{4}$ Quality Control Direction,

5 Process Development Direction. Center for Genetic Engineering and Biotechnology. P.O. Box 6162, Havana 10600, Cuba

${ }^{2}$ Tobacco Research Institute. Aguiar \#360 bel Obispo and Obrapía. Havana 10100, Cuba

E-mail: rodolfo.valdes@cigb.edu.cu

Introduction: Hepatitis B virus infection is the most common cause of liver disease worldwide [1]. Vaccines against this virus have been available since 1980s [2,3] and the immense majority of these vaccines uses the HBsAg as the active pharmaceutical ingredient. Affinity separation is a well stablished technique for the purification and recovery of biological molecules [4,3]. Within this tecnique, $\mathrm{mAb}$ for Hepatitis B surface antigen immunopurification have been successfully used to obtain this antigen for human use [6-8] but regulatory constrains of $\mathrm{mAb}$ production in animals, the high cost and the low scale-up capacity of mammalian cell culture production brakes the massive application of this technique for large-scale production of this biological. Alternatively, the use 
of plants for antibody production has gained great importance in the last years $[9,10]$. It represents a cost-effective system for large-scale production of pharmaceutical antibodies and provides an additional level of safety compared with ascites and mammalian cells production systems because plant viruses are not known to infect humans. In this work, different ligand densities of the $N$. tabacum-derived antibody HB-01 [11] specific for the aminoacid sequence CKTCTT of the Hepatitis B surface antigen "a" determinant were evaluted. The determination of the optimal ligand density contributes valuable information to reduced the product cost, the level of the released ligand from the matrix and to make a precise estimation of the production capacity.

Antigen and monoclonal antibody sources: A recombinant strain of Pichia pastoris was fermented in saline medium supplemented with glycerol and its expression was induced with methanol. The rHBsAg was purified according to the procedure described by Pentón et al., [3]. The hybridoma (CB.Hep-1) was previously generated by Fontirrochi et al., (1993) [12]. Briefly, it was obtained by fusion of $\mathrm{Sp} 2 / 0$ Ag14 myeloma cells and spleen cells of a BALB/c mouse immunized with a natural HBsAg. The CB.Hep-1 is routinely employed as an immunoligand at the downstream purification process of the rHBsAg used for the production of a commercially available Hepatitis B vaccine (Heberbiovac HBTM, HeberBiotec S.A., Cuba) [3].

Plant-derived antibody HB-01 production: Tobacco plants expressing the anti-HBsAg plantibody HB-01 generated as described by Ramírez et al., [11] were used for this study. Seedlings were ransplanted at a rate of 14-plants/square meter. Leaves were then harvested and ground in PBS, $\mathrm{pH} 8.0$ and ascorbic acid by a Fitzmill Comminutor (The Fitzpatrick Company, USA). The green fraction was removed from the juice by centrifugation at $1500 \mathrm{rpm}$ in a Rina basket centrifuge (Riera Nadeu S.A., Spain). This supernatant was centrifuged again at 16,000 $\mathrm{rpm}, 4^{\circ} \mathrm{C}$ in a CEPA tubular centrifuge (Carl Padberg, Germany) and pumped to the recombinant protein A Streamline column (Amersham-Biosciences, Uppsala, Sweden). Finally, a buffer exchange was carried out by means of a gel filtration chromatography using Sephadex G-25 (Amersham-Biosciences, Uppsala, Sweden). It was performed in a BP113/120 column using as equilibrium buffer $20 \mathrm{mM}$ Tris $/ 150 \mathrm{mM} \mathrm{NaCl}, \mathrm{pH} 7.6$ and a flow rate of $129 \mathrm{~cm}$ $\mathrm{h}^{-1}[13]$.

Immunoaffinity matrix and immunoaffinity chromatography: Sepharose CL-4B (AmershamBiosciences, Uppsala, Sweden) was activated by the
$\mathrm{CNBr}$ method [14]. The monoclonal antibody CB.Hep-1 and the plantibody HB-01 were coupled as recommended by the manufacturer AmershamBiosciences, Uppsala, Sweden. Gels $(12.1 \mathrm{~mL})$ were packed into PD10 columns (Amersham-Bioscences, Uppsala, Sweden) and equilibrated with $20 \mathrm{mM}$ Tris$\mathrm{HCl} / 3 \mathrm{mM}$ EDTA/3mM NaCl pH 7.2. Adsorption and elution flow rates were 20 and $35 \mathrm{~cm} \mathrm{~h}^{-}{ }^{1}$, respectively. Columns were loaded with $7 \mathrm{mg}$ of a purified rHBsAg diluted in the equilibrium buffer. Bound antigen was eluted with $20 \mathrm{mM}$ Tris $/ 3 \mathrm{M} \mathrm{KSCN} / 3 \mathrm{mM}$ EDTA, pH 7.0, and monitored at $280 \mathrm{~nm}$. Buffer exchange was performed by gel filtration chromatography in a PD10 column with Sephadex G-25 (Amersham-Biosciences, Uppsala, Sweden).

Estimation of antigen-specific antibody activity by enzyme linked immunoassay: A polystyrene (PE) microplate (Costar, Cambridge, USA) was coated with $10 \mu \mathrm{g}$ per well of $\mathrm{HBsAg}$ in $0.1 \mathrm{M} \mathrm{NaHCO}_{3}$ buffer for $20 \mathrm{~min}$ at $50{ }^{\circ} \mathrm{C}$. After this step samples were added to the plate in $0.05 \%$ Tween 20 in PBS and incubated for $1 \mathrm{~h}$ at $37^{\circ} \mathrm{C}$. After several washings with $0.05 \%$ Tween $20 / \mathrm{PBS}$ the plate was incubated for $1 \mathrm{~h}$ at $37^{\circ} \mathrm{C}$ with an anti-mouse IgG-horseradish peroxidase conjugate (Sigma Chemical, St. Louis, USA). The reaction was revealed using $100 \mu \mathrm{L} /$ well of $0.05 \%$ orthophenylenediamine and $0.015 \% \mathrm{H}_{2} \mathrm{O}_{2}$ in citrate buffer, $\mathrm{pH} 5.0$ [15].

Estimation of matrix released antibody by enzyme linked immunoassay: A sandwich ELISA determined the concentration of $\operatorname{IgG}$ released from the matrixes. Briefly, a plate (Costar, Cambridge, USA) was coated with sheep anti-mouse polyclonal immunoglobulin overnight at $4^{\circ} \mathrm{C}$. The plate was blocked for $30 \mathrm{~min}$ at $37^{\circ} \mathrm{C}$. Wells were washed and eluted samples from the immunosorbents were added and incubated for $3 \mathrm{~h}$ at $37^{\circ} \mathrm{C}$ with $1 \%$ non-fat milk phosphate buffered saline. After washing the plate, it was incubated with $100 \mu \mathrm{L} /$ well of a goat anti-mouse polyclonal immunoglobulin-horseradish peroxidase conjugate (Sigma Chemical, St. Louis, USA). The reaction was then revealed using $100 \mu \mathrm{L} /$ well of $0.05 \%$ orthophenylenediamine and $0.015 \% \mathrm{H}_{2} \mathrm{O}_{2}$ in citrate buffer (pH 5.0) and stopped with $50 \mu \mathrm{L} /$ well of $1.25 \mathrm{M} \mathrm{H}_{2} \mathrm{SO}_{4}$.

Protein determination, SDS-PAGE and Western blot: Protein concentration was performed by the method described by Lowry et al. [16], using BSA as standard material. Samples were analyzed by electrophoresis on $12.5 \%$ SDS-polyacrylamide gels as described by Laemmli [17]. Separated proteins were stained with Coomassie blue R-250 and analyzed by gel densitometry. Proteins were transferred by a semi-dry electrophoretic transfer with $25 \mathrm{mM}$ 


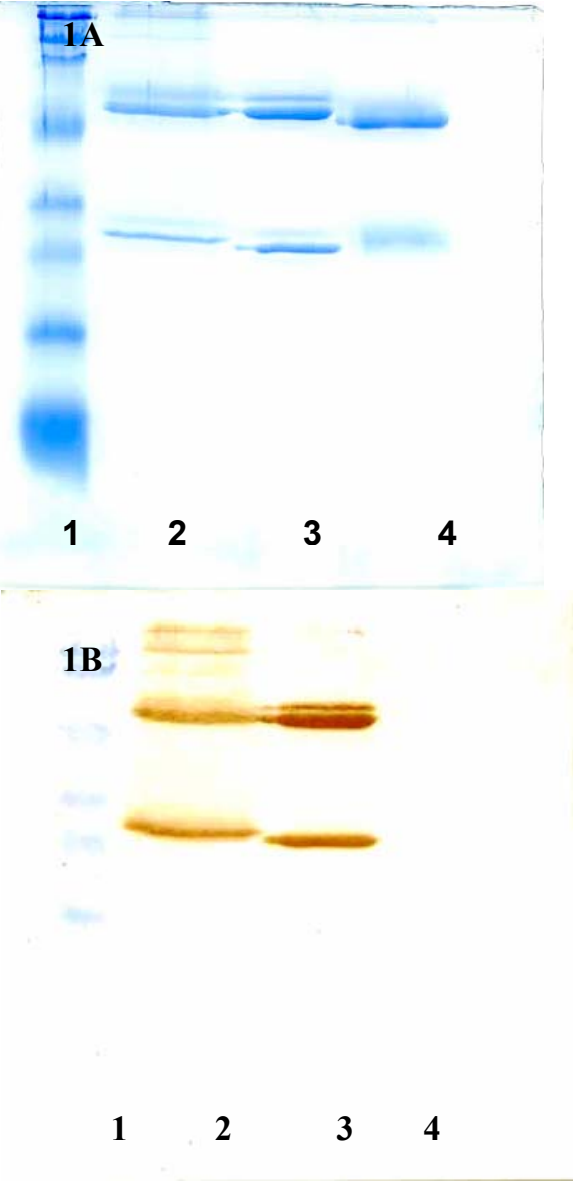

Fig. 1. SDS-PAGE of plantibody HB-01 purified by expanded bed adsorption method and mAb CB.Hep-1 purified by packed bed adsorption. A. Lane 1, molecular weight marker (myosin, 209 $\mathrm{kDa}$; b-galactosidase, $124 \mathrm{kDa}$; bovine serum albumin, $80 \mathrm{kDa}$; ovalbumin, $49 \mathrm{kDa}$; carbonic anhydrase, $34.8 \mathrm{kDa}$; soybean trypsin inhibitor, $28.9 \mathrm{kDa}$; lysozyme, $20.6 \mathrm{kDa}$; and aprotinin, 7.10 $\mathrm{kDa}$ ); lane 2, plantibody HB-01 (5 $\mu \mathrm{g})$; lane 3, mAb CB.Hep-1 (5 $\mu \mathrm{g})$, lane 4 , goat $\operatorname{IgG}(5 \mu \mathrm{g})$. B. Immunoblot analysis, samples were transferred onto nitrocellulose and antibodies were detected with a horseradish peroxidase labeled goat anti-mouse IgG. Lane 1, pre-stained molecular weight marker; lane 2, plantibody HB-01 (5 $\mu \mathrm{g})$; lane 3, mAb CB.Hep-1 (5 $\mu \mathrm{g})$, lane 4, goat IgG (5 $\mu \mathrm{g}$, negative control).

Tris/ $192 \mathrm{mM}$ glycine $/ 20 \%$ methanol at $25 \mathrm{~V}$ for 20 min onto a nitrocellulose membrane (Scheiler \& Schuell, Daseel, Germany) [13]. After incubating with $1 \%$ non-fat milk in PBS for $1 \mathrm{~h}$ at $37^{\circ} \mathrm{C}$ the membrane was washed with PBS-T and incubated for $1 \mathrm{~h}$ at room temperature with $100 \mu \mathrm{L}$ of a goat anti-mouse IgG conjugate to horseradish peroxidase (Sigma Chemical, St. Louis, USA). Bands were visualized by reacting with the substrate solution $(5 \mathrm{mg}$ of 3, 3-diaminobenzidine $/ 10 \mu \mathrm{L}$ of $30 \% \mathrm{H}_{2} \mathrm{O}_{2} / 10 \mathrm{~mL}$
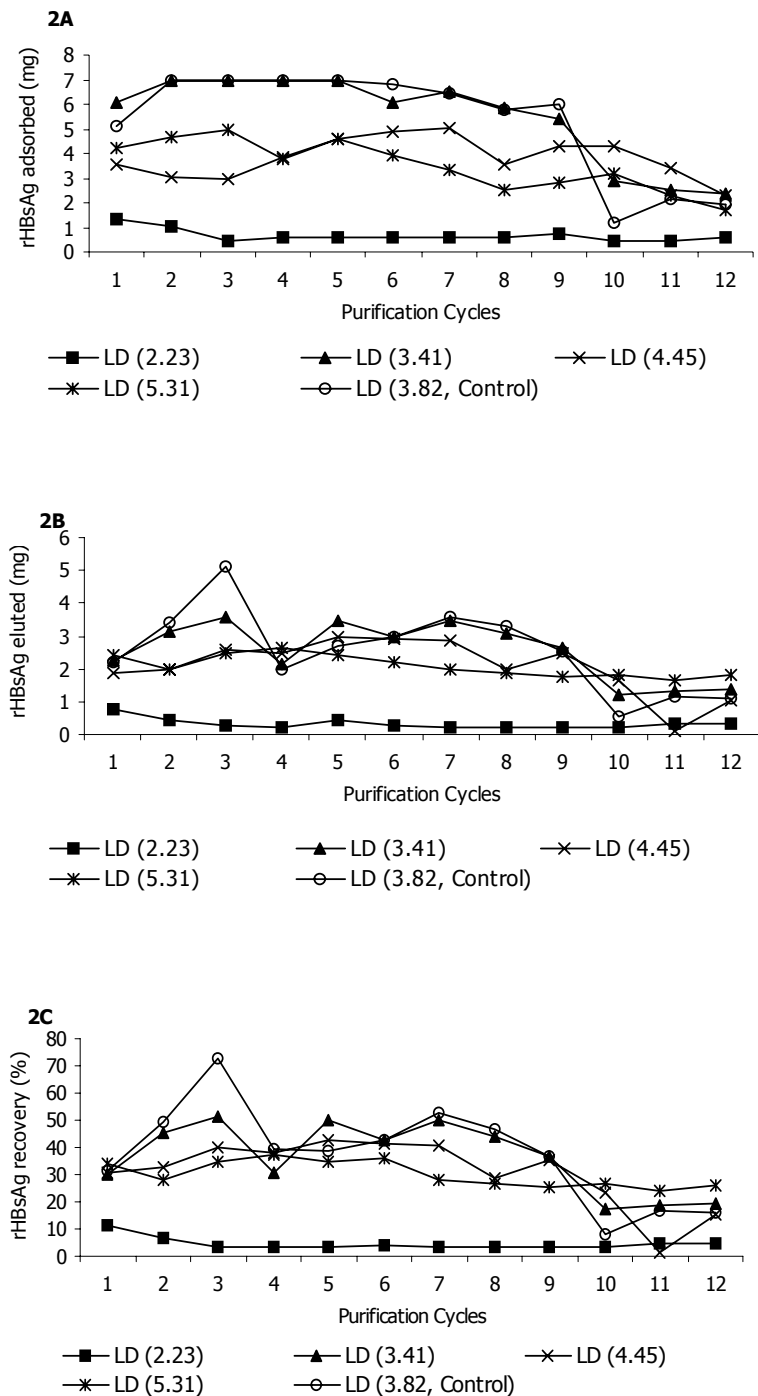

Fig. 2. Immunopurification behavior of the plantibody HB-01 immunosorbents. 2A. Amount of $\mathrm{rHBsAg}$ adsorbed in each purification cycle. 2B. Amount of rHBsAg eluted in each purification cycle. 2C. Recovery of the rHBsAg in each purification cycle.

PBS). The reaction was stopped with deionized water.

Statistical analysis: Adsorption and elution capacity, recovery and IgG released were evaluated by ANOVA (simple factor). The significance level $(a)$ was 0.05 and the STATISTICA for Window application was used.

Results and discussion: Many pharmaceutical proteins of mammalian origin have been synthesized in plants [9]. Most plant-derived proteins have been 
Table 1

Coupling efficiency to Sepharose CL-4B and immunopurification behavior of the plantibody HB-01 columns in twelve purification cycles

\begin{tabular}{|c|c|c|c|c|c|c|c|}
\hline $\begin{array}{l}\text { Ligand } \\
\text { density } \\
(\mathrm{mg} / \mathrm{mL})\end{array}$ & $\begin{array}{l}\text { Coupled } \\
\text { protein } \\
(\mathrm{mg})\end{array}$ & $\begin{array}{l}\text { Coupling } \\
\text { efficiency } \\
(\%)\end{array}$ & $\begin{array}{l}\text { Total } \\
\text { adsorbed } \\
\text { rHBsAg } \\
(\mathrm{mg})\end{array}$ & $\begin{array}{l}\text { Total } \\
\text { eluted } \\
\text { rHBsAg } \\
(\mathrm{mg})\end{array}$ & $\begin{array}{l}\text { Recovery } \\
(\%)\end{array}$ & $\begin{array}{l}\text { Average of } \\
\text { released IgG } \\
(\mathrm{ngIgG} / \mu \text { grHBsAg) }\end{array}$ & $\begin{array}{l}\text { Released } \\
\text { IgG } \\
(\%)\end{array}$ \\
\hline 2.23 & 26.98 & 92.21 & $8.11 \pm 0.26$ & $4.03 \pm 0.16$ & $4.52 \pm 2.26$ & $8.07 \pm 11.85$ & 0.118 \\
\hline 3.41 & 41.26 & 92.48 & $65.55 \pm 1.81$ & $30.68 \pm 0.89$ & $46.80 \pm 12.79$ & $0.13 \pm 0.08$ & 0.023 \\
\hline 4.45 & 53.84 & 94.62 & $45.69 \pm 0.83$ & $24.93 \pm 0.85$ & $54.56 \pm 12.32$ & $0.79 \pm 0.50$ & 0.009 \\
\hline 5.31 & 64.21 & 98.05 & $42.09 \pm 1.03$ & $24.99 \pm 0.32$ & $59.37 \pm 4.94$ & $3.29 \pm 0.99$ & 0.031 \\
\hline $\begin{array}{l}3.82 \text { Con- } \\
\text { trol }\end{array}$ & 46.22 & 98.10 & $63.46 \pm 2.20$ & $30.69 \pm 1.26$ & $48.33 \pm 17.91$ & $0.88 \pm 0.50$ & 0.037 \\
\hline
\end{tabular}

produced in transgenic tobacco plants and extracted directly from leaves. It represents a special challenge because this molecule must assemble correctly to recognize its antigen. Therefore, a deep characterization of the applicability of plantibodies is mandatory for its approval. In such sense, the main goal of this work was to evaluate the immunopurification behavior of a plant-derived HBsAg specific antibody coupled to Sepharose CL-4B at different ligand densities.

Immunoaffinity chromatography is a separation method based on specific and reversible interaction between an antigen and a matrix bound antibody. In this case, this technique acquired a higher meaning because this antibody is specific for the "a" determinant of the hepatitis B virus, which is important to raise a protective immune response against this virus in human [18].

To purify the rHBsAg, the plantibody HB-01 was obtained from batches of $400 \mathrm{~kg}$ of leaves with high purity $>90 \%$ (Fig. 1) and coupled to Sepharose CL$4 \mathrm{~B}$. Its immunopurification performance was evaluated using $12.1 \mathrm{~mL}$ of matrix that represents the $0.1 \%$ of the production scale. Several experiments were previously done at this scale demonstrating a rHBsAg recovery of $30-50 \%$ and comparability between the antigen purified at both scales.

In this study, the coupling efficiency was over $92 \%$ for a final ligand density of $2.23,3.41,3.82$, 4.45 and $5.31 \mathrm{mg} / \mathrm{mL}$ respectively. However, this parameter was always inferior in the case of the plantibody HB-01. Each column purified about 24.93$30.69 \mathrm{mg}$ of rHBsAg in 12 purification cycles (Table 1). The statistical analysis of the immunopurification parameters (rHBsAg: adsorption capacity, elution capacity, and recovery) did not show significant differences $(p>0.9212)$ corroborating the similitude between the mouse-derived immunoaffinity column behavior with those where the plantibody HB-01 was coupled at a ligand density of 3.41, 4.45 and 5.31 $\mathrm{mg} / \mathrm{mL}$ (Fig. 2 and Table 1). Conversely, only 8.11 $\mathrm{mg}$ rHBsAg were adsorbed and $4.03 \mathrm{mg}$ eluted from the matrix coupled with plantibody at a ligand density of $2.23 \mathrm{mg} / \mathrm{mL}$ showing very significant differences ( $p=5.96715 \mathrm{E}-11$ or $p<0.001)$ with the rest of ligand densities (Table 1). This may be explained by the fact that at low antibody amount in regards to the number of active groups could compromise also the antigen recognition site with the matrix where there are several potential linkage points with the activated groups.

Ligand leakage contributes impurities to the product. Taking into consideration that this antigen is intended for pharmaceutical use, this parameter raises great importance. This immunoaffinity chromatography is the first step of the HBsAg chromatographic purification process, therefore an IgG contamination $\leq 3 \mathrm{ngIgG} / \mu \mathrm{grHBsAg}$ has been previously established as the approved co-elution level [6]. The average IgG detectable level never exceeded the approved limit (Table 1). A value close to the limit was only observed at the ligand density of $5.31 \mathrm{mg} / \mathrm{mL}$ constituting this another aspect against the use of high ligand densities.

Several factors can cause a loss of column capacity during a repeated operation. One of the most important is the irreversible denaturalization of the antibody, usually caused by harsh elution conditions [19]. The plantibody HB-01 columns (LD: 3.41, 4.45, and 5.31) showed a similar elution capacity decrease as compared to the mouse-derived mAb column (Fig. 2). These rapid decreases seem to depend on the use of the chaotropic agent in the elution buffer and on the fouling of the matrix with nonspecific adsorbed antigen. This trend could not be attributed to other contaminants because the applied 
rHBsAg was always pure $(\geq 95 \%)$. In addition, the ligand leakage is not the major cause of this elution capacity decrease because the total released IgG was lower than $0.029 \%$ for plantibody HB-01 columns and $0.037 \%$ for mouse-derived $\mathrm{mAb}$ column of the total coupled IgG (Table 1).

Conclusion: These results support the feasibility of using the plantibody HB-01 for large-scale immunopurification of the rHBsAg for human use at a ligand density of $3.47 \mathrm{mg} / \mathrm{mL}$ because it demonstrated the same immunopurification behavior of the mouse-derived antibody column routinely used for this purpose, confirming this new alternative to overcome constrains of $\mathrm{mAb}$ production in mice.

\section{References}

[1] H.D. Shen, K.B. Choo, S.D. Lee, Y.T. Tsai, S.H. Han. Hepatitis B Virus DNA in leukocytes of patients with Hepatitis B virus-associated liver disease. J. Med. Virol. 1986; 18: 201 211.

[2] G.A. Bitter. K.M. Egan, W. N. Burnette, B. Samal, J. C. Fieschko, D. L. Peterson, M. R. Downing, J. Wypych, K. E. Langley. Hepatitis B vaccine produced in yeast. J. Med. Virol 1988; 25: 123-140

[3] E. Pentón, L. Herrera, V. Muzio, V. Ramírez, A. García, C. Duarte, C. Ruiz, M. Izquierdo, L. Pérez, G. Fontirrochi, M. González, M. Nazabal, A. Beldarían, G. Padrón, J. García, G. de la Riva, A. Santiago, F. Ayán, R. Páez, A. Agraz, R. Díaz, Y. Quiñónez. Method for obtaining recombinant surface antigen of hepatitis B virus of higher immunogenic capacity and use there of in vaccine preparation. Eur. Pat. Apl 480; 1992: 525 .

[4] H. A. Chase. The use of affinity adsorbents in expanded bed processes. Journal of Molecular Recognition 1998; 11: 217 221.

[5] R. H. Clemmitt, H. A. Chase. Facilitated downstream processing of a histidine-tagged protein from unclarified E. coli homogenates using immobilized metal affinity expanded-bed adsorption. Biotechnology and Bioengineering 2000; 67; 2 : 206-216.

[6] R. Valdés, B. Reyes, T. Alvarez, J. García, J.A. Montero, A. Figueroa, L. Gómez, S. Padilla, D. Geada, M.C. Abrahantes, L. Dorta, D. Fernández, O. Mendoza, N. Ramírez, M Rodríguez, M. Pujol, C. Borroto J. Brito, Hepatitis B surface antigen immunopurification using a plant-derived antibody produced in large scale, Biochem Biophys Res Commun. 2003; 310: 742-747

[7] E. Hardy, E. Martínez, D. Diago, R. Díaz, D. González, L.
Herrera. Large-scale production of recombinant hepatitis B surface antigen from Pichia pastoris. Journal of Biotechnology 2000; 77: 157-167.

[8] A. Agraz, C.A. Duarte, L. Costa, L. Pérez, R. Páez, V. Pujol, G.J. Fontirrochi, Immunoafinity purification of recombinant hepatitis B surface antigen fron yeast using a monoclonal antibody. J. Chromatogr. A. 1994; 672: 25-33.

[9] J. K-C.Ma, P.M.W. Drake, P. Christou. The production of recombinant pharmaceutical proteins in plants. Nature Reviews 2003 ; 4: 794-805.

[10] L. Miele. Plant as bioreactors for biopharmaceuticals: regulatory considerations. Tibetec $1997 ; \mathbf{1 5}: 45-50$

[11] N. Ramírez, M. Rodríguez, M. Ayala, J. Cremata, M. Pérez, A. Martínez, M. Linares, Y. Hevia, R. R. Páez. R. Valdés, J. Gavilondo, G. Relaman-Housein. Expression and characterization of an anti-(hepatitis B surface antigen) glycosylated mouse antibody in transgenic tobacco (Nicotiana tabacum) plants and its use in the immunopurification of its target antigen. Biotechnol. Appl. Biochem. 2003; 38: 223-230.

[12] G. Fontirrochi, M. Dueñas, M.E. Fernández de Cossio, P. Fuentes, M. Pérez, D. Mainet, M. Ayala, J.V. Gavilondo, C. Duarte, A mouse hybridoma cell line secreting IgG and IgM antibodies with specificity for the Hepatitis B virus surface antigen, Biotecnologia Aplicada. 1993; 10: 24-30.

[13] R. Valdés, L. Gómez, S. Padilla, J. Brito, B. Reyes, T. Alvarez, O. Mendoza, O. Herrera, W. Ferro, M. Pujol, V. Leal, M. Linares, Y. Hevia, C. García, L. Milá, O. García, R. Sánchez, A. Acosta, D. Geada, R. Paez, J.L. Vega, C. Borroto, Large-scale purification of an antibody directed against hepatitis B surface antigen from transgenic tobacco plants. Biochem Biophys Res. Commun. 2003; 308: 94-100

[14] J. Kohn, M. Wilchek. The Use of Cyanogen Bromide and Other Novel Cyanylating Agents for the Activation of Polysaccharide Resins," Applied Biochemistry and Biotechnology 1984; 9: 285-305.

[15] R. Valdés, L. Leyva, E. González, D. Mainet, L. Costa. Caracterización de anticuerpos monoclonales contra el antígeno de superficie del virus de la hepatitis B. Biotecnología Aplicada 1994; 11: 219-224.

[16] D.H. Lowry, N.J. Rosembrough, A.L. Far, R.J. Randal. Protein measurements with the folinphenol reagent. J. Biol. Chem. 1951; 193: 265-269.

[17] U.K. Laemmli. Cleavage of structural proteins during the assembly of head of bacteriophage T4. Nature. 1970; 227 680-685.

[18] M.E. Fernández de Cossío, T. Díaz, A. Galván, R. Valdés, E. González, M. Ayala, J. Díaz, M. Bestagno, O. Burrone, J. Gavilondo. Antigen recognition characteristics and comparative performance in immunoaffinity purification of two monoclonal antibodies specific for the hepatitis B virus surface antigen. Journal of Biotechnology 1997; 56: 69-80.

[19] M. Wilchek, T. Miron. Thirty years of affinity chromatography. Reactive \& Functional Polymers. 1999; 41: 263-268. 